\title{
Constraints to Participation in Income Generating Enterprises among Youths in Birnin Gwari LGA, Kaduna State
}

\author{
Adebayo Aworeni Awotodunbo \\ Leventis Foundation (Nig) LTD/GTE \\ Dogon Dawa, Kaduna \\ bayoawotodunbo67@yahoo.com
}

\begin{abstract}
Youths, who are the most important target group for human resources development, also constitute the foundation of sustainable development. For sustainable food production and viable agricultural development, youths need to occupy a very central stage. This research was carried out in Birnin Gwari Local Government Area (LGA) of Kaduna State to assess the constraints to participation of youth in Agricultural and other potential income generating enterprises. Combination of survey and oral interview were used to collect data from 100 youths randomly sampled from secondary schools in the LGA. The data collected were analysed using descriptive statistics, Chi square and Pearson product moment correlation.

The study reveals that respondents' age, sex and extent of participation are significantly related to participation constraints at $p<0.05$. Religion of the respondents is however not significantly related to participation constraints at $p<0.05$. It is therefore recommended that all stakeholders in agriculture and rural development must come up with policies and reforms that would further encourage youths' participation in agriculture and other rural income generating enterprises in the zone.
\end{abstract}

\section{INTRODUCTION}

The typology of hunger developed by the United Nations Development Programme (UNDP) when formulating the Millennium Development Goals (MDGs) of hunger reduction (UNDP, 2003) reveals that of 852 million people in the world who suffer from hunger, about 800 million live in developing countries, and, in rural areas as small farmers. Despite living as farmers, they are unable to feed themselves adequately from the resources at their disposal, let alone generating extra income for themselves. They are faced with problems like restricted access to credit and other agro-inputs, lack of a well developed transport system and poor infrastructure, which often makes these families dependent on a few middlemen; while agricultural extension services may generally not be available. This situation makes farmers poorer such that youths; who are supposed to be future generation of farmers loose interest in agriculture and agriculture related enterprises. While Yahaya (2003) viewed youths from socio-cultural perspective as individuals or persons in a particular society that are considered youths by that society, Arokoyo and Auta (1999) asserted that only the participation of people who are energetic, creative, innovative, productive and committed could bring about the expected development in 


\section{Journal of Agricultural Extension}

Vol. 13 (1) June, 2009

Agriculture. That means, for any meaningful development in agriculture, youths must participate actively. Webster Student Dictionary defined participation as the act of taking part or has a share in common with others. Adu, Adeogun and Adejoba (2002) reported that for community participation in forestry-related activities to achieve the desired goals of increased productivity and consequently, food security, the involvement of the youths is inevitable. In Nigeria, there are much research efforts on adults than youths' participation in food production. This research work was, therefore, carried out to assess the constraints to participation among youths in agricultural and other income generating enterprises in the area.

This study therefore addressed the following specific objectives, to:

1. determine the demographic characteristics of the respondents

2. identify the prevalent income generating enterprises in the area

3. determine the extent of respondents' participation in such enterprises

4. identify factors that constrained their participation in the identified enterprises

5. make recommendations to strengthen youths' participation in the identified enterprises.

\section{Hypotheses}

The following hypotheses stated in the null form were tested:

1. There is no significant relationship between age of respondents and their constraints to participation

2. There is no significant relationship between respondents' religion and their constraints to participation

3. There is no significant relationship between respondents' sex and their constraints to participation

4. There is no significant relationship between respondents' extent of participation and their constraints to participation

\section{METHODOLOGY}

This study was carried out in Birnin Gwari Local Government Area of Kaduna State. The level of development of agriculture and other income generating enterprises were very high in the Birnin Gwari Inspectorate Division from where respondents were selected. From a comprehensive list of 18 schools in the inspectorate division, $30 \%$ i.e 5 schools were randomly selected for inclusion in the sample. All students from JSS2 to SS3 constitute the population for the study. From the class register in each school, 10 students each from the junior and the senior secondary were sampled to give 20 from each school. A total of 100 secondary school students were used for this study. Questionnaire and oral interview were used to collect data from the respondents. The independent variables measured in this study include age, religion, sex as well as extent of participation in agricultural and income generating enterprises; which was measured on a 5- point likert-type scale with response options: very high, high, moderate, low and very low, using ten agricultural enterprises related activities: land preparation, planting, weeding, chemical application, harvesting, processing, marketing, vending, trading, crafting. The possible maximum extent of participation score was 50 while the least was 10 . 
The dependent variable was constraints to participation in income generating enterprises, which was measured on a 5- point likert-type scale with response options: very strong, strong, moderate, weak and very weak; using ten constraint factors: absence of production inputs, lack of finance or starting fund, lack of market for enterprises, infrastructural problem, high cost of inputs, restricted access to farmland and other production equipment, unavailability of labour, cultural restraints, religion restraints, family and other social problems. The maximum possible constraints score was 50 while the least was 10. Descriptive statistics were used to describe the data while Chi-square and Pearson product moment correlation were used to test the hypotheses.

\section{RESULTS AND DISCUSSION}

\section{Respondents demographic characteristics}

Table 1 reveals that $70 \%$ of the respondents are male while $30 \%$ are female, which implies that more male are enrolled in the schools than females in the area. While $20 \%$ of the respondents are Christians, $80 \%$ are Moslems, indicating that Christianity and Islamic religions are more popular in the area. The age structure of the youths in the table shows that $52 \%$ are between the ages of 15 years and 19 years. However, the average age of the youth was 18.84 years, implying that youths in the area are still relatively young and are expected to be energetic, fully committed to and participates in the development of agriculture and other income generating activities in the area.

TABLE 1: Distribution of respondents according to Sex, age and religion

\begin{tabular}{lcc}
\hline Characteristics & Frequency & Percentage \\
\hline Sex & 70 & 70 \\
Male & 30 & 30 \\
Female & 100 & 100 \\
Total & & \\
Religion & 20 & 20 \\
Christian & 80 & 80 \\
Moslem & 0 & 0 \\
Traditional & 100 & 100 \\
Total & & \\
Age (in years) & 10 & 10 \\
14 and below & 52 & 52 \\
$15-19$ & 30 & 30 \\
$20-24$ & 08 & 08 \\
25 and above & 100 & 100 \\
Total & & \\
\hline Source:Field Survy & & \\
\hline
\end{tabular}




\section{Journal of Agricultural Extension}

Vol. 13 (1) June, 2009

Income generating enterprises practiced, opportunities to participate, actual participation, extent of participation and reasons for not participating

The most practiced income generating enterprises as shown in Table 2 was farming (62\%). Food processing $(10 \%)$ and craft works $(3 \%)$ were not as practiced as Food vending $(13 \%)$ and trading $(12 \%)$ in the area. However, all the income-generating enterprises are being carried out in the area. Sixty eight percent of the respondents had opportunities to participate in full while $32 \%$ had opportunity to participate in part in such income generating activities. While $40 \%$, most of whom are male actually participated in full, $60 \%$ could only participate in part. However, $70 \%$ fall within very low to moderate extent of participation, while $30 \%$ fall within high to very high extent of participation. While $10 \%$ did not participate for lack of skills required, $30 \%$ and $10 \%$ lacked access to starting fund and feared the risks involved, respectively. Twenty percent were constrained by market for produce while $5 \%$ were constrained by culture and religion. From the foregoing, it may be implied that fear of the risks involved, in addition to culture or religion which secludes female youths to well-fenced family compound in the area, may prevent most of them from participating in outside engagements. Adu et al., (2002), discovered that the major constraint to youths participation in forestry related activities was inadequate knowledge of techniques involved. 
TABLE 2: Distribution of Respondents according to the income generating enterprises practiced in their communities, opportunities to participate, actual form of participation, extent of participation and reasons for not participating in full

\begin{tabular}{|c|c|c|}
\hline Characteristics & Frequency & Percentage \\
\hline \multicolumn{3}{|l|}{ Income Generating } \\
\hline \multicolumn{3}{|l|}{ Enterprises Practiced } \\
\hline Farming & 62 & 62 \\
\hline Trading & 12 & 12 \\
\hline Food Processing & 10 & 10 \\
\hline Food vending & 13 & 13 \\
\hline Crafts & 03 & 03 \\
\hline Total & 100 & 100 \\
\hline \multicolumn{3}{|c|}{$\begin{array}{l}\text { Opportunity to participate } \\
\text { in full }\end{array}$} \\
\hline Yes & 68 & 68 \\
\hline No & 32 & 32 \\
\hline Total & 100 & 100 \\
\hline \multicolumn{3}{|l|}{ Actual participation form } \\
\hline Full & 40 & 40 \\
\hline Part & 60 & 60 \\
\hline Total & 100 & 100 \\
\hline \multicolumn{3}{|l|}{ Extent of participation } \\
\hline Very high & 20 & 20 \\
\hline High & 10 & 10 \\
\hline Moderate & 14 & 14 \\
\hline Low & 33 & 33 \\
\hline Very low & 23 & 23 \\
\hline Total & 100 & 100 \\
\hline \multicolumn{3}{|l|}{$\begin{array}{l}\text { Reasons for not } \\
\text { participating in full }\end{array}$} \\
\hline Lack required skills & 10 & 10 \\
\hline No adequate information & 05 & 05 \\
\hline No fund/working capital & 30 & 30 \\
\hline No production inputs & 15 & 15 \\
\hline Against our culture & 05 & 05 \\
\hline Against our religion & 05 & 05 \\
\hline No market for produce & 20 & 20 \\
\hline Fear of risks & 10 & 10 \\
\hline Total & 100 & 100 \\
\hline
\end{tabular}

Source: Field Survey 2008 


\section{Relationship between Sex, Religion and constraints to participation}

Table 3 reveals that there is a significant relationship between respondents sex and their constraints to participation $\left(X^{2}=8.73 ; p<0.05\right)$. This implies that sex is a strong determinant of the youths' participation in income generating enterprises in the area. Most of the female in the area were secluded and prevented from participating in outside activities. However, the relationship between the respondents' religion and their constraints to participation is not significant; implying that religion cannot be used to explain youths' constraints to participation in the income generating enterprises in their communities.

TABLE 3: Relationship between Respondents' Sex and Religion and their constraints to participation

\begin{tabular}{llll} 
Characteristics & $\mathbf{X}^{2}$ Cal & $\mathbf{X}^{2}$ Tab & Decision \\
\hline Sex & 8.73 & 5.99 & Significant \\
Religion & 1.67 & 9.49 & Not Significant \\
\hline
\end{tabular}

Source: Field Survey 2008

Relationship between respondents' age, extent of participation and respondents' constraints to participation

Table 4 shows that significant relationships exist between both age of respondents $(r$ cal $=$ 0.213 ; $p<0.05$ ) and extent of their participation in income generating enterprises ( $r$ cal $=0.72$; $\mathrm{p}<0.05$ ) and their constraints to participation. Francis (2002) reported that, in general, compared to adults, youths are disadvantaged in their access to production resources like initial capital, market space and experience. These constraints expose youths to greater risk than adults.

TABLE 4: Relationship between respondents' age, extent of participation and respondents' constraints to participation

\begin{tabular}{llll}
\hline Characteristics & R cal & R tab & Decision \\
\hline Age & 0.213 & 0.195 & Significant \\
Participation Extent & 0.72 & 0.195 & Significant \\
\hline
\end{tabular}

Source: Field Survey 2008 


\section{Journal of Agricultural Extension \\ Vol. 13 (1) June, 2009}

\section{CONCLUSION AND RECOMMENDATIONS}

The result of this study reveals that, while the most practiced income generating enterprises in the area was farming, lack of access to starting fund or working capital and production risks limited youths' participation in the enterprises in the area. It is recommended that youths be organized into viable groups and provided with entrepreneurial development skills, other support services and credit facilities without the requirement of tangible collateral. Youths should be assisted to identify business opportunities, establish businesses and link with better global markets.

\section{REFERENCES}

Adu A.O, M.O. Adeogun and O.R. Adejoba (2002), "Participation of youths in forestry-related activities in Oyo and Ogun states of Nigeria" In stakeholders participation for strengthening agricultural extension practice and food security in Nigeria. Proceedings of the $8^{\text {th }}$ annual national conference of the agricultural extension society of Nigeria, $16^{\text {th }}-$ $19^{\text {th }}$ September, 2002. P.32-38

Arokoyo, T and S.T Auta (1999), "Extension strategies for reaching rural youths". Conference paper proceedings held at NAERLS conference hall, $20^{\text {th }}-24^{\text {th }}$ July In Journal of agricultural extension, vol. 3, 1999, p.39-44

Francis, C (2002) "Youths entrepreneurship: Meeting the key policy challenges" Background paper prepared for YES secretariat, Oxford University, England, pp. 33

UNDP (2003), “Drafting growth strategies” In Development and Cooperation, No. 1, 2005

Webster's Student Dictionary of the English Language. International Encyclopedic Edition. Trident Press International.

Yahaya, M.K (2003), "Determinant of youth participation in change programmes in rural Nigeria" In Anthropologists, 5 (3): 101-106, Anth- 05-2-101-106-2003-Yahaya-M-K-Text.pdf. Retrieved January 20, 2009. 